\title{
UNILATERAL INCOMPLETE DOUBLE URETER
}

Kaini Pfoze, Kalpana Thounaojam, Begendro N.

1. Assistant Professor. Department of Anatomy, Jawaharlal Nehru Institute of Medical Sciences, Porompat, Imphal, Manipur.

2. Assistant Professor. Department of Anatomy, Jawaharlal Nehru Institute of Medical Sciences, Porompat, Imphal, Manipur.

3. Medical Student. Department of Anatomy, Jawaharlal Nehru Institute of Medical Sciences, Porompat, Imphal, Manipur.

\section{CORRESPONDING AUTHOR:}

Dr. Kaini Pfoze,

Department of Anatomy,

JNIMS, Imphal, Manipur.

E-mail: kainipfoze@yahoo.com

ABSTRACT: Double ureter is a result of premature division of the ureteric bud. The ureters may join in the lower third of their course and open through a common orifice into the bladder. If they open independently into the bladder, the ureter draining the upper pelvis opens into the bladder below the opening of the other ureter. Patients with double ureter or double pelvis are more likely to develop urinary infection and calculi.

KEY WORDS: Double ureter, ureteric bud, premature splitting, infection, calculi

INTRODUCTION: The duplication of the ureter may be complete or incomplete. When incomplete it is called a bifid ureter. Both the conditions are due to premature division of the ureteric bud during early development 1 . The ureteric bud is an outgrowth from the caudal end of the mesonephric duct ${ }^{2}$. Cases of Familial double or bifid ureters have been reported in the past even though it is a rare occurrence. It is an autosomal dominant condition ${ }^{3}$. Duplication of the ureters is the most common anomaly of the urinary tract. The present report is a case of unilateral incomplete double ureter of the left side with no associated anomalies.

REPORT: During the routine dissection of a cadaver in the department of Anatomy JNIMS Imphal, the unilateral incomplete double ureter was encountered by the dissecting team. It was a male cadaver of about 50 years. The anomaly was detected only on the left side as seen in Fig.1. Apart from the double ureter, the shape and size of both the kidneys were equal and normal. The ureter draining the upper pelvis appeared longer and of a relatively smaller calibre. In the lower part the two ureters joined together and opened into the urinary bladder jointly (Fig.2). The location of the orifice was similar to that of the normal ureter.

There have been many reports of the occurrence of double ureter encountered during routine dissection and also during diagnostic radiological procedures. Previous reports suggested the association of this condition with many other congenital anomalies ${ }^{4}$. Nearly $10 \%$ of all human beings are born with a congenital anomaly of the urogenital system 5 . The duplication of the upper urinary tract is one of the commonest anomalies and occurs in about 1 in 160 individuals ${ }^{6}$. Double ureters may remain asymptomatic for the whole life of a person. Nonetheless, the condition is often complicated by recurrent urinary tract infection and calculi 7 . 
The bifid or double ureter may be due to disturbances during early development. The duplex ureter may be the result of an autosomal dominant gene which is of low penetrance i.e. it fails to manifest in some patients ${ }^{8}$. Double ureters can be of two types a) Complete - when the two ureters drain their specific areas and open individually into the urinary bladder b) Incomplete - wherein the two ureters join each other and become one before opening into the urinary bladder. The duplication may be unilateral or bilateral.

The complete duplication has been thought to be due to early splitting of the ureteric bud where the twin ureters are so closely placed that by expansion of the lower end of the Wolffian duct, they would be drawn on to the bladder floor as separate openings. The incomplete or branched ureter is due to the premature splitting of the ureteric bud before it reaches the nephrogenic cord 9 .

\section{REFERENCES:}

1. Sadler TW; Urogenital system, Langman's Medical Embryology, 9th edition. Lippincott Williams and Wilkins, 2004, pp 321-6

2. Hamilton WJ and Mossman HW; Urogenital System, Hamilton, Boyd and Mossman's Human Embryology $4^{\text {th }}$ edition The Macmillan Press Ltd., London, 1976 pp 377-397

3. Atwell JD, Cook PL, Howell CJ, Hyde I, and Parker BC; Archives of Diseases in childhood ,1974; 49:390

4. Angulo CJ, Unda UM, Florescorral N; Blind ending bifid ureter associated with adult congenital hydronephrosis, Archives Esp Urology 1991; 44:869-71

5. Burkland CE; The significance of genetic and environmental factors in urogenital disease, Journal of Urology 1958; 79: 532

6. Campbell MF and Harrison JH; Urology, $3^{\text {rd }}$ edition, vol. 2,Philadelphia: WB Saunders, 1970, pp1488

7. Giannokopoulus X, Chambilomatis $\mathrm{P}$, Thirothoulakis M, and Seferiadis G; The blind ending bifid ureter. Internal Urology \& Nephrology1986; 26: 161-5

8. Whitaker J and Danks DM; A study of inheritance of duplication of the kidneys and ureters. Journal of Urology 1966;95:176

9. Pohlman AG; concerning the embryology of kidney anomalies. AM med 1904; 1: 159

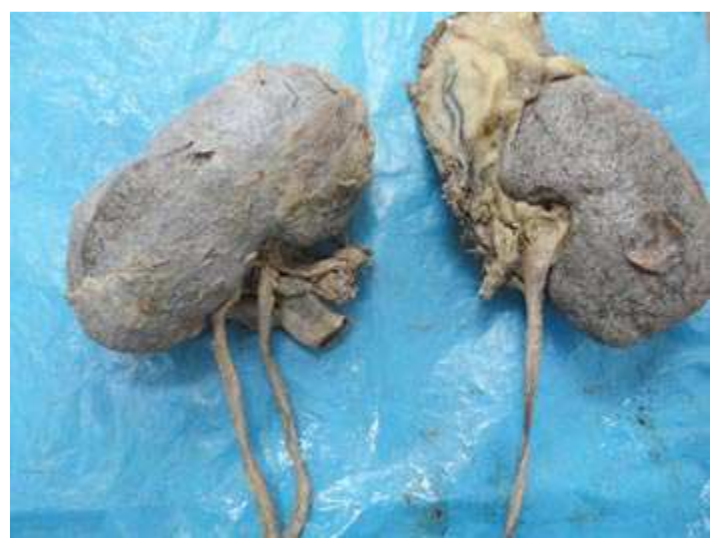

Fig.1. Double ureters left Kidney:

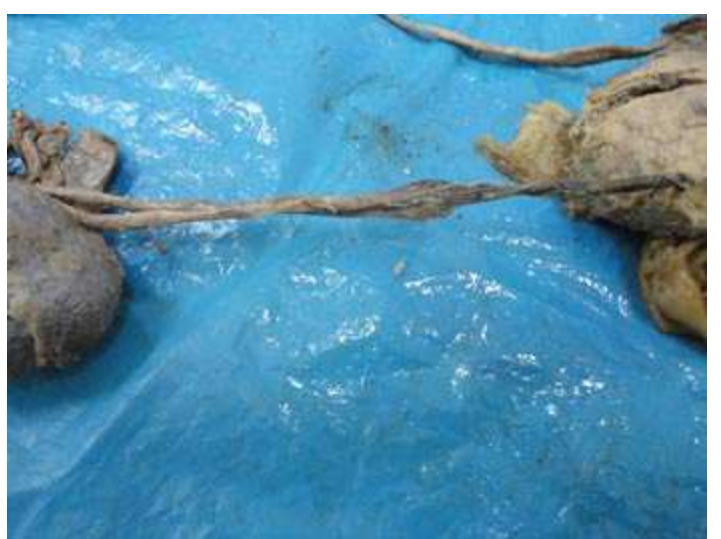

Fig.2. Two ureters merged before entering the Posterior view urinary bladder 